\title{
sciendo
}

\section{COMPARISON OF YIELD, COMPOSITION AND QUALITY OF MILK OF POLISH HOLSTEIN-FRIESIAN COWS IN CONVENTIONAL AND AUTOMATIC MILKING SYSTEMS*}

\author{
Magdalena Kolenda ${ }^{1 \star}$, Dariusz Piwczyński ${ }^{1}$, Marcin Brzozowski ${ }^{1}$, Beata Sitkowska ${ }^{1}$, Piotr Wójcik $^{2}$ \\ ${ }^{1}$ Department of Animal Biotechnology and Genetics, Faculty of Animal Breeding and Biology, \\ UTP University of Science and Technology, Mazowiecka 28, Bydgoszcz 85-084, Poland \\ ${ }^{2}$ Department of Cattle Breeding, National Research Institute of Animal Production, \\ 32-083 Balice n. Kraków, Poland \\ •Corresponding author: kolenda@utp.edu.pl
}

\begin{abstract}
The aim of the present study was to evaluate the changes in selected production and functional traits of Polish Holstein-Friesian cows after switching from a conventional (CMS) to an automatic milking system (AMS). The study consisted of 3398 Polish Holstein-Friesian dairy cows, from 16 herds in which CMS was changed to AMS. Cows were in their $1^{\text {st }}(\mathrm{L1})$ or $2^{\text {nd }}$ lactation (L2). The data consisted of milk yield (MY, kg), fat content (FC, \%), protein content (PC, \%), solids (SO, \%), lactose content (LC, \%), urea content (MU, mg/l), somatic cell count (SCC, thous./ml) and somatic cell score (SCS, log). The milking system had a significant impact on milk yield, fat, lactose, solids, and urea contents. Regardless of lactation number, milk derived from CMS was characterised by higher values for FC, PC, SO, SCC and SCS, while milk from AMS had higher MY, LC and MU. Multifactor analysis of variance also confirmed significant effect of herd, season, herd $\times$ milking system interaction on SCS in milk of cows in L1. In the studied herds change from CMS to AMS was evaluated separately for cows in L1 and L2. The transitioning from CMS to AMS resulted in the decrease of fat content in $6 \mathrm{L1}$ and $7 \mathrm{~L} 2$ herds, solids in $8 \mathrm{~L} 1$ and $5 \mathrm{~L} 2$ herds. SCS in milk also decreased in $4 \mathrm{~L} 1$ and $5 \mathrm{~L} 2$ herds. The change caused the increase of MY in $11 \mathrm{~L} 1$ and $9 \mathrm{~L} 2$ herds, lactose content in $6 \mathrm{~L} 1$ and $4 \mathrm{~L} 2$ herds and urea content in $9 \mathrm{~L} 1$ and $10 \mathrm{~L} 2$ herds. AMS may positively affect milk yield and health status, however, the change of milking system should be also accompanied by the change in herd management.
\end{abstract}

Key words: cattle, automatic milking system, conventional milking system, milk composition, milk quality

The Food and Agriculture Organization has estimated that all over the world around 150 million households are involved in milk production (Hemme and Otte,

\footnotetext{
*Source of research financing: work financed from statutory activity.
} 
2010). In Poland in 2016 dairy production provided a source of income for 270000 farms (Sobczyński et al., 2018).

In recent years dairy farms have undergone a change, caused by changes in technology, a decrease in the number of dairy farms and an increase in the number of cows per herd. On top of that, the number of farms equipped with an automatic milking system (AMS) has increased. This change is caused by a constant demand for labour. Farmers aim to reduce labour time and improve their profitability at the same time. Robots have been proven to be a breakthrough system that improves work on a dairy farm. AMS exempt breeders from performing pre- and post-milking tasks such as teat cleaning, attaching teat cups and disinfecting teats after each milking (de Koning, 2011; Waśkowicz et al., 2014).

To date, a number of studies have been conducted on AMS and CMS (transition from conventional), as well as on the comparison of both systems (Pezzuolo et al., 2017; Winnicki et al., 2017). The results obtained by various authors (de Koning, 2011; Österman et al., 2005) suggest that in some farms the increase in milk yield in AMS may be caused by a higher number of milkings per day, which improves lactation yield by $10-15 \%$. Some authors also point out that in AMS the udder health is often improved which may contribute to a better milk quality compared to milk obtained in CMS (Bogucki et al., 2014; Svennersten-Sjaunja and Pettersson, 2008). On the other hand, better results are not visible immediately after AMS installation. Moreover, CMS to AMS change also may impact milk composition and quality. The results provided by the above-mentioned authors are contradictory to each other, therefore, further research is needed to determine the effect of milking system on the aforementioned traits.

We predict that in the near future, the number of automatic robots will increase and more dairy farms will be equipped with AMS. This may be due to the rising costs of human labour and a subsequent need to reduce costs, changes in approach of young farmers who may be keener on using new technology in their dairy farms, as well as a better availability of new solutions (Schewe and Stuart, 2015).

The aim of the present study was to evaluate the changes in selected production and functional traits of Polish Holstein-Friesian cows after switching from a conventional to an automatic milking system. We hypothesise that this change positively affects milk yield, composition and hygienic quality in dairy cattle.

\section{Material and methods}

\section{Animals and data collection}

The study consisted of data derived from 16 different herds of Polish HolsteinFriesian dairy cows, in which the change from CMS to AMS occurred between 2010 and 2013. Depending on a farm, from one up to four "Astronaut A4" robots by Lely (Maassluis, The Netherlands) were installed. The animals were kept in similar conditions and fed using the Partial Mixed Ration feeding system and had access to feed ad libitum. Data was derived from the automated registration system SYMLEK 
provided by the Polish Federation of Cattle Breeders and Dairy Farmers (PFHBiPM) and concerned a total of 3398 cows that calved between 2008 and 2015. Selected production and functional traits were analysed. The data included in the study consisted of daily milk yield (MY, kg), fat content (FC, \%), protein content (PC, \%), solids (SO, \%), lactose content (LC, \%), urea content (MU, mg/l), somatic cell count (SCC, thous./ml) and somatic cell score (SCS, log). Calving dates and duration of milking were also recorded. Data was collected in the first and second full lactations. The study evaluated the quality of milk based on SCC in test milkings. A total of 28655 test milkings in $1^{\text {st }}$ and $2^{\text {nd }}$ lactations were recorded.

The studied herds $(\mathrm{H})$ were marked with the letters $\mathrm{A}-\mathrm{P}$ and the calving season (S) was divided in two periods: summer (May - October) and winter (November April). The studied population was divided according to milking system (MS): CMS dates of successive calving and culling date < AMS implementation date; AMS dates of successive calving and culling date $>$ AMS implementation date. The group of cows that started their production in CMS but finished in AMS, was excluded from the study. The general characteristics of each herd are presented in Table 1.

Table 1. General characteristics of the tested herds

\begin{tabular}{|c|c|c|c|c|c|c|c|c|}
\hline \multirow[b]{2}{*}{ Herd } & \multicolumn{3}{|c|}{ CMS } & \multicolumn{5}{|c|}{ AMS } \\
\hline & \begin{tabular}{|c|} 
no. of cows \\
per CMS herd
\end{tabular} & $\begin{array}{c}\text { housing } \\
\text { system }\end{array}$ & $\begin{array}{c}\text { milking } \\
\text { system }\end{array}$ & $\begin{array}{c}\text { year of AMS } \\
\text { installation }\end{array}$ & $\begin{array}{c}\text { AMS } \\
\text { barn }\end{array}$ & $\begin{array}{c}\text { no. } \\
\text { of robots }\end{array}$ & $\begin{array}{l}\text { lying } \\
\text { areas }\end{array}$ & $\begin{array}{c}\text { walking } \\
\text { areas }\end{array}$ \\
\hline A & $26-50$ & FS & MP & 2013 & M & 1 & $\mathrm{RM}$ & G \\
\hline B & $26-50$ & $\mathrm{TS}$ & WMM & 2012 & $\mathrm{~N}$ & 1 & $\mathrm{RM}$ & G \\
\hline $\mathrm{C}$ & $26-50$ & FS & WMM & 2012 & $\mathrm{~N}$ & 2 & $\mathrm{RM}$ & G \\
\hline D & $26-50$ & FS & WMM & 2013 & $\mathrm{~N}$ & 2 & $\mathrm{RM}$ & G \\
\hline $\mathrm{E}$ & $>100$ & FS & MP & 2013 & $\mathrm{~N}$ & 4 & SS & G \\
\hline $\mathrm{F}$ & $26-50$ & FS & MP & 2012 & M & 1 & $\mathrm{~S}$ & $\mathrm{C}$ \\
\hline $\mathrm{G}$ & $51-100$ & FS & MP & 2011 & M & 1 & $\mathrm{RM}$ & $\mathrm{C}$ \\
\hline $\mathrm{H}$ & $\leq 25$ & FS & MP & 2013 & $\mathrm{~N}$ & 2 & $\mathrm{RM}$ & $\mathrm{G}$ \\
\hline I & $26-50$ & FS & MP & 2011 & $\mathrm{~N}$ & 3 & SS & G \\
\hline $\mathrm{J}$ & $26-50$ & FS & MP & 2011 & M & 1 & $\mathrm{RM}$ & $\mathrm{C}$ \\
\hline $\mathrm{K}$ & $26-50$ & $\mathrm{TS}$ & WMM & 2012 & $\mathrm{~N}$ & 1 & $\mathrm{RM}$ & G \\
\hline $\mathrm{L}$ & $>100$ & FS & MP & 2013 & M & 1 & $\mathrm{RM}$ & G \\
\hline M & $\leq 25$ & $\mathrm{TS}$ & WMM & 2011 & $\mathrm{~N}$ & 1 & $\mathrm{RM}$ & G \\
\hline $\mathrm{N}$ & $51-100$ & FS & MP & 2012 & M & 1 & RM & G \\
\hline $\mathrm{O}$ & $>100$ & FS & WMM & 2012 & M & 1 & $\mathrm{RM}$ & $\mathrm{C}$ \\
\hline $\mathrm{P}$ & $\leq 25$ & FS & MP & 2010 & M & 2 & $\mathrm{RM}$ & G \\
\hline
\end{tabular}

FS - free-stalls, TS - tie-stalls; MP - milking parlour, WMM - wired milking machine; $\mathrm{N}$ - new; $\mathrm{M}$ - modernised; RM - rubber mats, $\mathrm{S}$ - straw; $\mathrm{SS}$ - straw with a separate; $\mathrm{G}$ - grates; $\mathrm{C}$ - concrete.

\section{Statistical analysis}

Studied features of milk yield, composition and hygienic quality for cows in their $1^{\text {st }}$ (L1) and $2^{\text {nd }}$ lactation (L2) were statistically pre-characterised with the use of 
arithmetic mean, standard deviation and coefficient of variation. Data on SCC was subjected to logarithmic transformation to obtain somatic cell score (SCS):

$$
S C S=\log _{2} \times \frac{S C C}{100000}+3,(\text { PFHBiPM, 2016), }
$$

where $S C S$ was somatic cell score ( $\log )$ and $S C C$ was somatic cell count (thous. $/ \mathrm{ml})$.

Preliminary classification models that were used in statistical analyses included the effect of housing system in CMS (free-stalls, tie-stalls), milking system (milking parlour, wired milking machine), as well as the type of AMS barn (modernized, new), the type of lying area (rubber mats, straw, straw with a separate), walking areas type (concrete, grates) (Table 1). Due to the lack of significant impact of the above-mentioned factors on tested traits the herd effect was introduced in the final classification model.

A multifactor analysis of variance was performed to confirm factors statistically affecting milk yield, milk composition and SCS in $1^{\text {st }}$ and $2^{\text {nd }}$ lactations (SAS Institute Inc., 2014). The following linear model was used:

$$
Y_{i j k l m}=\mu+B X+a_{i}+b_{j}+c_{k}+d_{l}+(a b)_{i j}+(b c)_{j k}+\sqrt{3 x}+\sqrt{\frac{5}{4}}\left(3 x^{2}-1\right)+e_{i j k l m},
$$

where:

$y_{i j k l m}-$ phenotypic value of studied trait

$m$ - mean,

$B X$ - linear regression for age at calving,

$a_{i}$ - fixed effect of $i^{\text {th }}$ milking system (CMS, AMS),

$b_{j}$ - fixed effect of $\mathrm{j}^{\text {th }}$ herd $(\mathrm{A}-\mathrm{P})$,

$c_{k}$ - fixed effect of $\mathrm{k}^{\text {th }}$ season (summer: $\mathrm{V}-\mathrm{X}$, winter XI $-\mathrm{IV}$ ),

$d_{l}$ - random effect of $1^{\text {th }} \operatorname{cow}\left(1 . .2620\right.$ in $1^{\text {st }}$ lactation, $1 . .1339$ in $2^{\text {nd }}$ lactation),

$(a b)_{i j}$ - milking system $\times$ herd interaction,

$(a c)_{i k}$ - milking system $\times$ season interaction,

$(b c)_{j k}-$ herd $\times$ calving season interaction,

$\sqrt{3 x} ; \sqrt{\frac{5}{4}}\left(3 x^{2}-1\right)$ - covariates of Legendre polynomial, modified by Gengler et al. (1999),

$$
x=\frac{(2 t-5)}{t_{\text {max }}-t_{\text {min }}}-1
$$

where:

$t$ - date of test milking,

$t_{\max } ; t_{\min }-$ maximum and minimum duration of test milkings,

$e_{i j k l m}$ - random error.

Statistical analysis of the investigated traits was performed using MIXED procedure in the SAS 9.4 software (SAS Institute Inc., 2014). Groups of animals that 
were identified with the means of classification model were compared based on least squares means using the Scheffé test.

\section{Results}

Descriptive statistics of analysed traits are presented in Table 2. During the second lactation the analysis revealed higher values of milk yield $(29.25 \mathrm{~kg} /$ day vs. $25.90 \mathrm{~kg} /$ day for cows in L2 and L1, respectively), fat content (4.02\% vs. 3.99\%), protein content $(3.42 \%$ vs $3.34 \%)$, solids $(12.94 \%$ vs. $12.92 \%)$ as well as somatic cell score (3.55 vs. 3.18 ) and somatic cell count (442.82 thous./ml vs. 327.11 thous./ $\mathrm{ml})$. However, values for lactose (4.93\% vs. $4.83 \%$ for cows in L1 and L2, respectively) as well as urea content $(236.16 \mathrm{mg} / \mathrm{l} \mathrm{vs.} 230.14 \mathrm{mg} / \mathrm{l})$ were higher in milk of cows in the $1^{\text {st }}$ lactation. The average MY was higher in AMS than in CMS $(28.32 \mathrm{~kg} /$ day vs. $24.21 \mathrm{~kg}$ /day in L1 and $31.15 \mathrm{~kg} /$ day vs. $27.57 \mathrm{~kg} /$ day in L2).

Table 2. Descriptive statistics of the analysed traits

\begin{tabular}{l|c|c|c|c|c|r|r|r}
\hline \multirow{2}{*}{ Trait } & \multicolumn{5}{|c|}{$1^{\text {st }}$ lactation } & \multicolumn{4}{c}{$2^{\text {nd }}$ lactation } \\
\cline { 2 - 9 } & $\mathrm{n}$ & mean & SD & CV & $\mathrm{n}$ & mean & SD & CV \\
\hline Milk yield (kg/day) & 19163 & 25.90 & 7.92 & 30.57 & 19613 & 29.25 & 10.02 & 34.26 \\
Fat content (\%) & 18957 & 3.99 & 0.76 & 18.97 & 19342 & 4.02 & 0.81 & 20.07 \\
Protein content (\%) & 18960 & 3.34 & 0.35 & 10.54 & 19362 & 3.42 & 0.39 & 11.4 \\
Solids (\%) & 18960 & 12.92 & 0.94 & 7.25 & 19362 & 12.94 & 1.03 & 7.97 \\
Lactose content (\%) & 18960 & 4.93 & 0.18 & 3.74 & 19362 & 4.83 & 0.20 & 4.05 \\
Urea content (mg/l) & 18948 & 236.16 & 83.51 & 35.36 & 19348 & 230.14 & 82.71 & 35.94 \\
SCC (thous./ml) & 18966 & 327.11 & 2929.96 & 895.71 & 19374 & 442.82 & 4588.06 & 1036.10 \\
SCS (log) & 18966 & 3.18 & 1.83 & 57.51 & 19374 & 3.55 & 2.00 & 56.37 \\
\hline
\end{tabular}

$\mathrm{n}$ - number of observations, SD - standard deviation; CV - coefficient of variation (\%), SCC - somatic cell count, SCS - somatic cell score.

Multifactor analysis of variance confirmed significant effect $(\mathrm{P}<0.0001)$ of milking system $(\mathrm{MS})$, herd $(\mathrm{H})$, season $(\mathrm{S})$, age at calving, $\mathrm{H} \times \mathrm{MS}$ interaction on different milk parameters (Table 3). Herd as well as interaction between $\mathrm{H}$ and MS were indicated as factors that affected all traits. MS had a significant impact on milk yield, fat, lactose, solids and urea contents regardless of lactation number and in the L2 group also on SCS. In both L1 and L2 groups season and age at calving, as well as $\mathrm{S} \times \mathrm{MS}$ and $\mathrm{H} \times \mathrm{S}$ interactions had an impact on some of the recorded traits (Table 3).

Highly significant differences were reported for milk yield (least square means increased from CMS to AMS by $3.43 \mathrm{~kg} /$ day for L1 cows and $3.73 \mathrm{~kg} /$ day for L2 cows), fat (decreased by $0.19 \%$ and $0.18 \%$, respectively), lactose (increased by $0.03 \%$ in both lactations), solids (decreased by $0.21 \%$ in both lactations) and urea 
contents (increased by $28.32 \mathrm{mg} / 1$ and $36.09 \mathrm{mg} / 1$ in L1 and L2, respectively) (Table 4). No statistical influence of milking system was found on protein content in milk. Significant differences in relation to SCS recorded in milk obtained from cows milked in different milking systems were found only for L2 cows. LSM (least square means) values for SCS decreased from CMS to AMS, proving that the decrease of SCS after AMS introduction was highly significant $(\mathrm{P}<0.01)$ (Table 4). Analysing the coefficient of the variation of tested traits, it was noted that cows in L1 and L2 milked in AMS were characterised by a lower variability in milk yield and composition and higher in SCS compared to cows milked in CMS (Table 4).

Table 3. Significance of the influence of the main factors on the studied traits

\begin{tabular}{|c|c|c|c|c|c|c|c|c|}
\hline \multicolumn{2}{|l|}{ Trait } & $\begin{array}{l}\text { Milking } \\
\text { system } \\
(\mathrm{MS})\end{array}$ & $\begin{array}{c}\text { Herd } \\
(\mathrm{H})\end{array}$ & $\begin{array}{l}\text { Calving } \\
\text { season } \\
(\mathrm{S})\end{array}$ & $\begin{array}{c}\text { Age at } \\
\text { calving } \\
(\mathrm{AC})\end{array}$ & $\mathrm{S} \times \mathrm{MS}$ & $\mathrm{H} \times \mathrm{MS}$ & $\mathrm{H} \times \mathrm{S}$ \\
\hline \multicolumn{9}{|c|}{$1^{\text {st }}$ lactation } \\
\hline Milk yield & $\mathrm{F}$ & $178.94 * * *$ & $72.31 * * *$ & $4.30 *$ & $23.16 * * *$ & $15.68 * * *$ & $9.81 * * *$ & 1.39 \\
\hline Fat content & $\mathrm{F}$ & $55.10 * * *$ & $20.54 * * *$ & $9.79 * *$ & 2.19 & $13.34 * * *$ & $4.01 * * *$ & 1.39 \\
\hline Protein content & $\mathrm{F}$ & 0.02 & $10.83 * * *$ & 2.15 & $4.22 *$ & 3.05 & $8.67 * * *$ & 1.35 \\
\hline Lactose content & $\mathrm{F}$ & $11.44 * * *$ & $6.72 * * *$ & 2.62 & $12.62 * * *$ & 1.03 & $3.37 * * *$ & 1.25 \\
\hline Solids & $\mathrm{F}$ & $38.82 * * *$ & $14.37 * * *$ & $10.56^{* *}$ & 1.80 & $13.44 * * *$ & $4.77 * * *$ & 1.23 \\
\hline Urea content & $\mathrm{F}$ & $187.33 * * *$ & $120.18 * * *$ & 2.53 & 0.28 & 3.18 & $35.68 * * *$ & $3.13 * * *$ \\
\hline SCS & $\mathrm{F}$ & 2.92 & $9.50 * * *$ & $7.12 * *$ & 3.73 & 0.11 & $6.68 * * *$ & 1.17 \\
\hline \multicolumn{9}{|c|}{$2^{\text {nd }}$ lactation } \\
\hline Milk yield & $\mathrm{F}$ & $149.90 * * *$ & $65.70 * * *$ & $23.80 * * *$ & $25.28 * * *$ & 0.22 & $12.89 * * *$ & 1.05 \\
\hline Fat content & $\mathrm{F}$ & $44.52 * * *$ & $21.42 * * *$ & $8.06^{* *}$ & 0.19 & 0.29 & $4.28 * * *$ & 0.63 \\
\hline Protein content & $\mathrm{F}$ & 3.50 & $10.51 * * *$ & $26.77 * * *$ & $52.71 * * *$ & 0.74 & $5.50 * * *$ & $1.84 *$ \\
\hline Lactose content & $\mathrm{F}$ & $18.03 * * *$ & $8.29 * * *$ & 0.14 & $12.14 * * *$ & 0.03 & $3.89 * * *$ & 0.69 \\
\hline Solids & $\mathrm{F}$ & $34.55 * * *$ & $17.28 * * *$ & $17.46^{* * *}$ & $7.05 * *$ & 0.72 & $3.93 * * *$ & 1.02 \\
\hline Urea content & $\mathrm{F}$ & $322.98 * * *$ & $126.07 * * *$ & $5.93 *$ & 0.15 & $9.08 * *$ & $34.95 * * *$ & $3.70 * * *$ \\
\hline SCS & $\mathrm{F}$ & $9.38 * *$ & $11.04 * * *$ & 0.03 & $10.99 * * *$ & 0.33 & $6.40 * * *$ & 0.69 \\
\hline
\end{tabular}

$\mathrm{F}-$ empirical values of $\mathrm{F}$ statistics, $\mathrm{SCS}-$ somatic cell score; * $-\mathrm{P} \leq 0.05 ; * *-\mathrm{P} \leq 0.01 ; * * *-\mathrm{P} \leq 0.001$.

Table 4. Values of least square means (LSM), standard error (SE), coefficient of variation (CV, \%) for the studied traits depending on the milking system, separately for cows in $1^{\text {st }}$ and $2^{\text {nd }}$ lactation

\begin{tabular}{cl|c|c|c|c}
\hline \multirow{2}{*}{ Traits } & \multirow{2}{*}{} & \multicolumn{2}{c|}{$1^{\text {st }}$ lactation } & \multicolumn{2}{c}{$2^{\text {nd }}$ lactation } \\
\cline { 3 - 6 } & & CMS & AMS & CMS & AMS \\
\hline \multirow{2}{*}{1} & 2 & 3 & 4 & 5 \\
\hline Milk yield (kg/day) & LSM & $23.90 \mathrm{~A}$ & $27.33 \mathrm{~B}$ & $26.95 \mathrm{~A}$ & $30.68 \mathrm{~B}$ \\
& SE & 0.19 & 0.17 & 0.25 & 0.18 \\
Fat content (\%) & CV & 32.17 & 26.33 & 37.07 & 30.29 \\
& LSM & $4.17 \mathrm{~A}$ & $3.98 \mathrm{~B}$ & $4.19 \mathrm{~A}$ & $4.01 \mathrm{~B}$ \\
& SE & 0.02 & 0.02 & 0.02 & 0.02 \\
& $\mathrm{CV}$ & 19.32 & 18.26 & 20.73 & 19.17 \\
\hline
\end{tabular}


Table 4 - contd.

\begin{tabular}{ll|c|c|c|c}
\hline \multicolumn{1}{c}{1} & & 2 & 3 & 4 & 5 \\
\hline Protein content (\%) & LSM & 3.36 & 3.36 & 3.44 & 3.41 \\
& SE & 0.01 & 0.01 & 0.01 & 0.01 \\
& $\mathrm{CV}$ & 10.84 & 10.07 & 11.52 & 11.26 \\
Solids (\%) & LSM & $13.13 \mathrm{~A}$ & $12.92 \mathrm{~B}$ & $13.14 \mathrm{~A}$ & $12.93 \mathrm{~B}$ \\
& $\mathrm{SE}$ & 0.02 & 0.02 & 0.03 & 0.02 \\
& $\mathrm{CV}$ & 7.39 & 7 & 8.09 & 7.81 \\
Lactose content (\%) & LSM & $4.90 \mathrm{~A}$ & $4.93 \mathrm{~B}$ & $4.81 \mathrm{~A}$ & $4.84 \mathrm{~B}$ \\
& $\mathrm{SE}$ & 0.01 & 0.00 & 0.01 & 0.00 \\
& $\mathrm{CV}$ & 3.85 & 3.52 & 4.17 & 3.88 \\
Urea content (mg/l) & $\mathrm{LSM}$ & $209.94 \mathrm{~A}$ & $238.26 \mathrm{~B}$ & $203.42 \mathrm{~A}$ & $239.51 \mathrm{~B}$ \\
& $\mathrm{SE}$ & 1.5 & 1.43 & 1.61 & 1.21 \\
& $\mathrm{CV}$ & 40.5 & 27.02 & 41.39 & 29.07 \\
SCS (log) & $\mathrm{LSM}$ & 3.24 & 3.12 & $3.61 \mathrm{~A}$ & $3.38 \mathrm{~B}$ \\
& $\mathrm{SE}$ & 0.05 & 0.05 & 0.06 & 0.05 \\
& $\mathrm{CV}$ & 56.33 & 59.13 & 52.27 & 60.85 \\
\hline
\end{tabular}

CMS - conventional milking system, AMS - automatic milking system; SCS - somatic cell score; $\mathrm{AB}$ - least square means marked with different letters, within the group of cows in the $1^{\text {st }}$ or $2^{\text {nd }}$ lactation, differ statistically at $\mathrm{P} \leq 0.01$.

Table 5. The change in values (\%) of the studied traits after substituting conventional with automatic milking system depending on lactation number (calculated as the mathematical difference between values of different parameters in AMS and CMS)

\begin{tabular}{c|c|c|c|c|c|c|c|c}
\hline Lactation & Herd & $\begin{array}{c}\text { Milk } \\
\text { yield }\end{array}$ & $\begin{array}{c}\text { Fat } \\
\text { content }\end{array}$ & $\begin{array}{c}\text { Protein } \\
\text { content }\end{array}$ & $\begin{array}{c}\text { Lactose } \\
\text { content }\end{array}$ & Solids & $\begin{array}{c}\text { Urea } \\
\text { content }\end{array}$ & SCS \\
\hline 1 & 2 & 3 & 4 & 5 & 6 & 7 & 8 & 9 \\
\hline $1^{\text {st }}$ lactation & $\mathrm{A}$ & $+17.83^{* *}$ & $-10.03^{* *}$ & -0.62 & $+1.35^{*}$ & $-3.04^{* *}$ & +3.55 & $-16.98^{*}$ \\
& $\mathrm{~B}$ & $+27.19^{* *}$ & -4.04 & +0.65 & +1.16 & -1.24 & $-17.27^{* *}$ & -19.17 \\
& $\mathrm{C}$ & $+21.62^{* *}$ & $-4.85^{*}$ & -0.86 & +0.15 & $-2.04^{*}$ & $+40.34^{* *}$ & $+19.45^{*}$ \\
& $\mathrm{D}$ & $+17.35^{* *}$ & -3.73 & -2.02 & $+2.11^{* *}$ & -1.60 & $+46.16^{* *}$ & $-35.63^{* *}$ \\
& $\mathrm{E}$ & $-4.80^{* *}$ & +0.33 & +6.49 & $+0.64^{*}$ & $+1.72^{* *}$ & $-6.33^{* *}$ & $-22.33^{* *}$ \\
& $\mathrm{~F}$ & $+18.44^{* *}$ & $-9.18^{* *}$ & -1.11 & +0.93 & $-3.21^{* *}$ & $+8.86^{* *}$ & $+15.66^{*}$ \\
& $\mathrm{G}$ & $+17.26^{* *}$ & $-7.82^{* *}$ & -3.06 & -0.66 & $-3.48^{* *}$ & $+9.98^{* *}$ & +2.23 \\
& $\mathrm{H}$ & -1.86 & -2.87 & +0.51 & +0.49 & -1.24 & $+22.54^{* *}$ & -0.30 \\
& $\mathrm{I}$ & $+18.39^{* *}$ & $-8.74^{* *}$ & -3.06 & $+1.14^{*}$ & $-3.26^{* *}$ & -0.97 & +3.41 \\
& $\mathrm{~J}$ & +5.47 & -3.41 & +1.55 & -0.57 & -0.98 & $+73.80^{* *}$ & +5.47 \\
& $\mathrm{~K}$ & $+53.17^{* *}$ & $-10.04^{* *}$ & +1.09 & $+2.36^{* *}$ & $-2.84^{*}$ & $+78.53^{* *}$ & $-44.54^{* *}$ \\
& $\mathrm{~L}$ & $+10.66^{* *}$ & -3.21 & -3.21 & $-1.48^{*}$ & $-2.35^{*}$ & -6.32 & $+25.66^{* *}$ \\
& $\mathrm{M}$ & +14.70 & -2.58 & +1.56 & -1.59 & -1.09 & +8.53 & +14.70 \\
& $\mathrm{~N}$ & $+6.73^{*}$ & +3.70 & -2.09 & $+1.07^{*}$ & +0.21 & $+9.70^{* *}$ & +12.43 \\
& $\mathrm{O}$ & $+22.06^{* *}$ & -1.31 & +5.28 & +0.61 & +1.09 & +2.71 & -1.66 \\
$\mathrm{P}$ & +6.04 & -2.75 & -1.72 & +0.44 & $-1.94^{*}$ & $+9.19^{* *}$ & +5.06 \\
\hline
\end{tabular}


Table 5 - contd.

\begin{tabular}{c|c|c|c|c|c|c|c|c}
\hline 1 & 2 & 3 & 4 & 5 & 6 & 7 & 8 & 9 \\
\hline $2^{\text {nd }}$ lactation & $\mathrm{A}$ & $+21.04^{* *}$ & $-11.37^{* *}$ & -1.20 & +1.07 & $-3.36^{* *}$ & $+11.98^{* *}$ & $-28.39^{* *}$ \\
& $\mathrm{~B}$ & +6.68 & -0.79 & +2.44 & +0.86 & +0.19 & -6.12 & -9.74 \\
& $\mathrm{C}$ & $+17.73^{* *}$ & -0.18 & -0.34 & +0.38 & -0.39 & $+48.84^{* *}$ & $+51.11^{* *}$ \\
& $\mathrm{D}$ & $+16.16^{* *}$ & -1.99 & +0.31 & $+2.12^{* *}$ & -0.49 & $+47.30^{* *}$ & $-26.13^{* *}$ \\
& $\mathrm{E}$ & $-4.36^{*}$ & $+4.50^{* *}$ & +4.88 & +0.45 & $+2.58^{* *}$ & $-9.32^{* *}$ & $-19.26^{* *}$ \\
& $\mathrm{~F}$ & $+14.49^{* *}$ & $-7.75^{* *}$ & -2.50 & -0.03 & $-3.27^{* *}$ & +6.38 & $+25.49^{* *}$ \\
& $\mathrm{G}$ & $+12.68^{* *}$ & $-8.03^{* *}$ & -4.69 & -0.75 & $-3.85^{* *}$ & $+10.10^{* *}$ & +8.87 \\
& $\mathrm{H}$ & $+25.72^{* *}$ & $-8.39^{*}$ & -3.90 & -0.78 & $-4.55^{* *}$ & $+54.05^{* *}$ & +8.96 \\
& $\mathrm{I}$ & +3.57 & $-5.95^{* *}$ & -2.97 & $+1.15^{* *}$ & $-2.22^{* *}$ & $+7.44^{* *}$ & -9.05 \\
& $\mathrm{~J}$ & +5.19 & -3.32 & +0.91 & +0.79 & -1.06 & $+81.48^{* *}$ & -1.63 \\
& $\mathrm{~K}$ & $+46.89^{* *}$ & $-7.90^{* *}$ & +2.35 & +0.76 & -2.09 & $+62.47^{* *}$ & $-21.81^{*}$ \\
& $\mathrm{~L}$ & -3.10 & +0.22 & -0.80 & $-1.02^{* *}$ & -0.75 & +2.56 & -1.40 \\
& $\mathrm{M}$ & $+36.34^{* *}$ & -5.30 & -0.52 & +0.55 & -1.61 & $+18.01^{* *}$ & -5.17 \\
& $\mathrm{~N}$ & +6.28 & -1.60 & -5.65 & $+2.96^{* *}$ & -1.85 & +6.40 & -13.67 \\
& $\mathrm{O}$ & $+52.11^{* *}$ & $-4.94^{* *}$ & +2.17 & $+1.03^{* *}$ & -0.79 & +3.48 & $-27.13^{* *}$ \\
& $\mathrm{P}$ & +2.46 & -1.73 & -0.91 & +0.60 & -1.32 & $+11.77^{* *}$ & -6.84 \\
\hline
\end{tabular}

CMS - conventional milking system, AMS - automatic milking system; SCS - somatic cell score; * $\mathrm{P} \leq 0.05 ; * *-\mathrm{P} \leq 0.01$.

Since a significant impact of herd on the analysed traits as well as $\mathrm{H} \times \mathrm{MS}$ interaction were recorded, a comparative analysis between CMS and AMS was performed (Table 5). A relative (\%) difference was calculated between levels of milk parameters (AMS - CMS) in all 16 herds, however, the changes of analysed values differ throughout herds (Table 5). The conversion from CMS to AMS resulted in a decrease of fat content in $6 \mathrm{~L} 1$ and $7 \mathrm{~L} 2$ herds and solids in $8 \mathrm{~L} 1$ and $5 \mathrm{~L} 2$ herds. SCS in milk also decreased in 4 L1 and 5 L2 herds. The change caused the increase of MY in $11 \mathrm{~L} 1$ and $9 \mathrm{~L} 2$ herds, lactose content in $6 \mathrm{~L} 1$ and 4 L2 herds and urea content in $9 \mathrm{~L} 1$ and $10 \mathrm{~L} 2$ herds. These changes were proven to be statistically significant.

\section{Discussion}

\section{Milk yield and composition}

Milk from cows in $1^{\text {st }}$ and $2^{\text {nd }}$ lactation was obtained from CMS and AMS and its composition was analysed. Analysis of variance showed that, apart from the milking system, herd, season, age at calving and their interactions were the source of variability of the studied milk traits. These results are consistent with those obtained by previous studies (Pinedo and De Vries, 2017; Sitkowska et al., 2015). Due to the aim of the present study, the impact of change from CMS to AMS in terms of milk yield, composition and quality was thoroughly assessed. 
Higher MY obtained in the present study was recorded in AMS (LSM increased by $14.35 \%$ for cows in L1 and $13.84 \%$ for cows in L2). The average MY in AMS amounted to $28.32 \mathrm{~kg}$ /day for L1 cows, which constituted higher values than those obtained by Mulder et al. (2014), who reported the average daily MY to be $24.44 \mathrm{~kg}$ /day in AMS for $1^{\text {st }}$ lactation cows, while values in CMS were similar in both studies (24.21-24.31 kg/day). Sitkowska et al. (2015), who also investigated changes in milking parameters after the introduction of automatic milking robots, noted an increase in milk yield per day (by $3.39 \%$ and $2.15 \%$ in two different dairy herds), while in the present study the increase (by 5.47-53.17\%) was reported in 14 herds.

The present study also analysed fat, protein and solids contents revealing higher values obtained before AMS installation, which is in accordance with the results presented by Klungel et al. (2000) who reported that the average fat (\%) content in milk obtained before AMS introduction was at the level of $4.43 \%$, while after AMS installation $-4.37 \%$. Protein content also decreased after AMS introduction to $3.41 \%$ which was lower by $0.88 \%$ than in CMS. While the present study showed the solids in milk to be at the level of $12.92 \%$ and $12.93 \%$, respectively, for cows in L1 and L2 in AMS, Gołębiewski et al. (2011) reported higher solids content in milk (13.47\%). In the present study, lactose and urea contents in the milk of the dairy cows were proven to increase after AMS installation. Also Sitkowska et al. (2015) investigated content of fat, protein, lactose and solids in milk in CMS and AMS. They reported that milk obtained from cows milked in CMS had higher fat, lactose and solids contents $(4.13,4.93$ and $12.99 \%$, respectively); only protein content in milk was higher in AMS-derived milk (3.30\%).

The decrease in the fat and protein contents after AMS installation may result from an increase in milk yield rather than from the change in milking system. A number of researchers have mentioned a negative genetic correlation between milk yield and fat and protein contents in milk (Berry et al., 2013; Toghiani, 2012). Berry et al. (2013) estimated the genetic correlations between MY and fat and protein contents at the level of -0.49 and -0.51 , while Toghiani (2012) also reported negative genetic correlation between MY and protein $(-0.505)$.

Monitoring urea level in milk is important as it may enable farmers to indicate cases of health problems that may affect cow fertility. It has been stated that the optimal urea content in cow's milk is 150 - $300 \mathrm{mg} / \mathrm{l}$ (Czajkowska et al., 2015; Rzewuska and Strabel, 2013). In the study of Czajkowska et al. (2015), the content of urea in milk was within a normal range (206.4 mg/l). Similarly, Rzewuska and Strabel (2013) reported that during the $1^{\text {st }}$ lactation the average urea content was $230.1 \mathrm{mg} / \mathrm{l}$, and did not change significantly during the $2^{\text {nd }}$ lactation $(230.3 \mathrm{mg} / \mathrm{l})$. In the present study, we have observed a higher level of urea in L1 milk (236.16 mg/l) compared to L2 $(230.14 \mathrm{mg} / \mathrm{l})$. Also, it has been noted that MU increased after AMS installation (by 13.49-17.74\%, respectively in L1 and L2), which is in accordance with the results obtained by Vorobjovas et al. (2010), who reported an increase of 21.8\% after AMS introduction. Tousova et al. (2014), who also investigated the change in urea content in milk after changing from CMS to AMS, did not report any significant differences in the level of urea. It may be suggested that AMS provides 
cows with free access to milking robots as well as feed station. In AMS a feed ration is individually adjusted to the cow's capacity, which may result in more stable milk production. This may result in a decrease in variability of tested traits after switching from CMS to AMS.

The study included data from 16 dairy farms. It has been noted that the change from CMS to AMS affected some milk parameters in a different way. While generally MY, lactose and urea contents increased and fat, protein and solids contents decreased, this was not the case for all herds. Changing one milking system to another should also entail a change in herd management. Only a proper adjustment allows farmers to exploit the potential of milking robots (Tse et al., 2017).

\section{Somatic cell count and score}

Somatic cell count (SCC) in cows' milk, one of the functional traits, is conditioned by various genetic and non-genetic factors (Frössling et al., 2017; Sitkowska et al., 2017). Moreover, a higher level of somatic cell in milk is associated with mastitis (De Vliegher et al., 2012). The beginning of the $1^{\text {st }}$ lactation is very important for the future milk performance of a cow. A higher level of somatic cells in the cow's milk may be a reason for a lower milk yield in subsequent lactations; it also increases the risk of mastitis incidence (De Vliegher et al., 2012).

For the purposes of statistical analysis, SCC is often subjected to logarithmic transformation, which results in the creation of a new variable with a distribution similar to the normal distribution. The variable is called somatic cell score (SCS). Lactation number is a very important factor that affects SCC (Sitkowska et al., 2017), which was also confirmed in the present study with cows in L2 having higher values for this parameter. These results are in accordance with those described by Sitkowska (2008) who noted that multiparas' milk was characterised by a higher SCC content $(\mathrm{P}<0.01)$.

The present study showed significant differences in SCC between CMS and AMS. The level of somatic cells in cows' milk was lower in AMS for cows in their $1^{\text {st }}$ (not statistically significant) as well as $2^{\text {nd }}$ lactations $(\mathrm{P} \leq 0.01)$. Nevertheless, the impact of milking system on milk hygiene is not unequivocal. Frössling et al. (2017) also obtained ambiguous results - a significant decrease of SCC in milk after AMS installation was observed only in some years. Considering above-mentioned ambiguity of the results described in the literature, it can be concluded that further studies in this area are still justified.

Statistical analysis of the impact of $\mathrm{H} \times \mathrm{MS}$ interaction on SCS confirmed that the milking system affected SCS differently in different herds. Therefore, the conclusion may be drawn that the automation of milking process does not result in obligatory improvement of milk hygiene quality; it requires improvement of environmental conditions and herd management. It can be assumed that one of the reasons behind the beneficial effect of robotisation of the milking process may be the fact that cows have free access to a milking robot. As suggested by Sitkowska et al. (2015), AMS allows adjusting daily milking frequency to the individual needs of a cow. AMS also prevents too long breaks between successive milkings, which is important also in terms of SCC (Olde Riekerink et al., 2007). Olde Riekerink et al. (2007) noted that 
the level of somatic cells in milk increased geometrically if the break between milkings was longer than $7 \mathrm{~h}$. Moreover, a positive effect of changeover to AMS may also be caused by the construction and functional features of a robot. The data in the present study was derived from robots with a system of brushes that clean the area around and under teats. After each milking the brushes are disinfected, which helps to improve hygiene.

\section{Conclusion}

The change from a conventional to an automatic milking system significantly improved milk yield and composition. We observed an increase of daily milk yield, lactose and solids contents in milk, as well a decrease of fat, protein and solids contents. The results also showed significant interactions between season and milking system as well as herd membership and milking system, which affected several milk parameters. Moreover, the improvement of hygienic quality of milk after AMS installation (decrease of SCC) was also observed. This improvement might be caused by the extended functionality of a robot that guarantees that $100 \%$ of cows have their udders cleaned before milking, and which may alert farmers about potential mastitis cases based on changes in the recorded milk parameters. AMS installation cannot positively affect milk yield unless it is also accompanied by a change in herd management.

\section{Acknowledgements}

Research was carried out within statutory research BN-51/2019.

\section{References}

B erry D.P., C o yn e J., C ough 1 a n B., B urke M., M c C arthy J., Enright B., Crom ie A.R., M c P a r 1 a nd S. (2013). Genetics of milking characteristics in dairy cows. Animal, 7: 1750-1758.

B o gu ck i M., S a w a A., Neja W. (2014). Effect of changing the cow's milking system on daily yield and cytological quality of milk. Acta Sci. Pol. Zootech., 13: 17-26.

Czajkowska A., Sitkowska B., Piwczyński D., Wójcik P., Mroczkowski S. (2015). Genetic and environmental determinants of the urea level in cow's milk. Arch. Anim. Breed, 58: $65-72$.

Frössling J., Ohls on A., Hallén-S andgren C. (2017). Incidence and duration of increased somatic cell count in Swedish dairy cows and associations with milking system type. J. Dairy Sci., 100: 7368-7378.

G engler N., Tij a ni A., Wigg a n s G.R., Mis zt al I. (1999). Estimation of (co)variance function coefficients for test day yield with a expectation-maximization restricted maximum likelihood algorithm. J. Dairy Sci., 82: 1849.e1-1849.e23.

Gołębiewski M., Brzozowski P., Gołębiewski Ł. (2011). Analysis of lactation curves, milk constituents, somatic cell count and urea in milk of cows by the mathematical model of wood. Acta Vet. Brno, 80: 073-080.

H e m m e T., O t t e J. (2010). Status and Prospects for Smallholder Milk Production: A Global Perspective. Rome, Italy, FAO.

K l unge 1 G.H., S lagh u is B.A., Hog eve en H. (2000). The effect of the introduction of automatic milking systems on milk quality. J. Dairy Sci., 83: 1998-2003.

de Koning K. (2011). Automatic milking: Common practice on over 10,000 dairy farms worldwide. Proc. Dairy Research Foundation Symposium, Sydney, pp. 14-31. 
Muld e r H.A., Gro en A.F., D e J ong G., B i j m a P. (2014). Genotype × environment interaction for yield and somatic cell score with automatic and conventional milking systems. J. Dairy Sci., 87: $1487-1495$.

Olde Riekerink R.G.M., B arkema H.W., Veenstra W., Berg F.E., Stryhn H., Zad o k s R.N. (2007). Somatic cell count during and between milkings. J. Dairy Sci., 90: 3733-3741.

Österman S., Östens on K., Svennersten-Sjaunja K., Bertilss on J. (2005). How does extended lactation in combination with different milking frequencies affect somatic cell counts in dairy cows? Livest. Prod. Sci., 96: 225-232.

Pezzuolo A., Cill is D., Marine 11 o F., S a r tor i L. (2017). Estimating efficiency in automatic milking systems. J. Dairy Sci., 95: 929-936.

PFHBiPM (2016). Assessment of breeding value of black and white and red and white bulls of the PHF breed. Online: http://wycena.izoo.krakow.pl/doc/metody_oceny_2016_3.pdf

P in e d o P.J., D e Vrie s A. (2017). Season of conception is associated with future survival, fertility, and milk yield of Holstein cows. J. Dairy Sci., 100: 6631-6639.

R z ew u ska K., S trabe 1 T. (2013). Genetic parameters for milk urea concentration and milk traits in Polish Holstein-Friesian cows. J. Appl. Genet., 54: 473-482.

S c h e w e R.L., S t u a rt D. (2015). Diversity in agricultural technology adoption: How are automatic milking systems used and to what end? Agric. Human Values, 32: 199-213.

S i t k ow s k a B. (2008). Effect of the cow age group and lactation stage on the count of somatic cells in cow milk. J. Cent. Eur. Agric., 9: 57-61.

Sitkowska B., Piwczyński D., A erts J., Waśk owicz M. (2015). Changes in milking parameters with robotic milking. Arch. Anim. Breed, 58: 137-143.

Sitkowska B., Piwczyński D., A erts J., Kolenda M., Özkaya S. (2017). Detection of high levels of somatic cells in milk on farms equipped with an automatic milking system by decision trees technique. Turkish J. Vet. Anim. Sci., 41: 532-540.

Sobczyński B., Piwczyński D., Sitkowska B., Kolenda M., Piecuch K. (2018). Milk yield and milking parameters of selected breeds of dairy cows milked in the automatic milking system. Wiad. Zoot., 3: 148-158.

Svennersten-Sjaunja K.M., Pettersson G. (2008). Pros and cons of automatic milking in Europe. J. Anim. Sci., 86: 37-46.

To g h i a n i S. (2012). Genetic relationships between production traits and reproductive performance in Holstein dairy cows. Arch. Anim. Breed., 55: 458-468.

Tous ova R., Duchacek J., Stadnik L., Ptacek M., B eran J. (2014). The comparison of milk production and quality in cows from conventional and automatic milking systems. J. Cent. Eur. Agric., 15: 100-114.

Ts e C., B arke m a H.W., D e Vri e s T.J., Rushen J., P a jor E.A. (2017). Effect of transitioning to automatic milking systems on producers' perceptions of farm management and cow health in the Canadian dairy industry. J. Dairy Sci., 100: 2404-2414.

De Vliegher S., Fox L.K., P i epers S., Mc Dougall S., B arkema H.W. (2012). Invited review: Mastitis in dairy heifers: nature of the disease, potential impact, prevention, and control. J. Dairy Sci., 95: 1025-1040.

Vorobjovas G., Žila it is V., B anys A., Juozaitien é V., Jukna Č. (2010). The influence of automatic milking on milk yield and composition in cows. Vet. Ir. Zootech., 51: 71-76.

Wa sk ow i c z M., P i w c zy ńsk i D., S i tk ow sk a B., A ert s J. (2014). Efficiency of using milking robots in selected EU countries and the USA (in Polish). Prz. Hod, 6: 27-30.

Winnicki S., Jug ow ar J., A erts J., S obek Z. (2017). The effect of milking systems on the quantity and quality of cow milk. J. Res. Appl. Agric. Eng., 62: 193-196.

Received: 9 III 2020

Accepted: 7 IX 2020 